\title{
Retraction Note: Agricultural climate change based on GIS and remote sensing image and the spatial distribution of sports public services
}

\author{
Fan $\mathrm{He}^{1}$
}

Published online: 12 November 2021

C) Saudi Society for Geosciences 2021

Retraction Note to: Arabian Journal of Geosciences (2021) 14: 975 https://doi.org/10.1007/s12517-021-07202-3

The Editor-in-Chief and the Publisher have retracted this article because the content of this article is nonsensical. The peer review process was not carried out in accordance with the Publisher's peer review policy. The author disagrees with this retraction.

The original article can be found online at https://doi.org/10.1007/ s12517-021-07202-3.

\section{Fan $\mathrm{He}$}

hefan9588@163.com

1 Department of Public Education, Anhui Finance \& Trade Vocational College, Hefei 230601, China 